\title{
Skeletal Muscle and the Maintenance of Vitamin D Status
}

\author{
Mark S. Rybchyn ${ }^{1}\left(\mathbb{D}\right.$, Myriam Abboud ${ }^{1,2}{ }^{\mathbb{D}}$, David A. Puglisi ${ }^{1}$, Clare Gordon-Thomson ${ }^{1}$, \\ Tara C. Brennan-Speranza ${ }^{1,3}$, Rebecca S. Mason ${ }^{1}$ (D) and David R. Fraser ${ }^{4, * D}$ \\ 1 Department of Physiology, School of Medical Sciences and Bosch Institute, Faculty of Medicine and Health, \\ The University of Sydney, Sydney, NSW 2006, Australia; mark.rybchyn@sydney.edu.au (M.S.R.); \\ Myriam.abboud@zu.ac.ae (M.A.); dpug9928@alumni.sydney.edu.au (D.A.P.); \\ clare.gordon-thomson@sydney.edu.au (C.G.-T.); tara.speranza@sydney.edu.au (T.C.B.-S.); \\ rebecca.mason@sydney.edu.au (R.S.M.) \\ 2 Department of Health Sciences, College of Natural and Health Sciences, Zayed University, Dubai, \\ Abu Dhabi P.O. Box 144534, UAE \\ 3 School of Public Health, Faculty of Medicine and Health, The University of Sydney, Sydney, \\ NSW 2006, Australia \\ 4 Sydney School of Veterinary Science, Faculty of Science, The University of Sydney, Sydney, \\ NSW 2006, Australia \\ * Correspondence: david.fraser@sydney.edu.au; Tel.: +61-2-93512139
}

Received: 29 September 2020; Accepted: 21 October 2020; Published: 26 October 2020

\begin{abstract}
Vitamin D, unlike the micronutrients, vitamins A, E, and K, is largely obtained not from food, but by the action of solar ultraviolet (UV) light on its precursor, 7-dehydrocholesterol, in skin. With the decline in UV light intensity in winter, most skin production of vitamin D occurs in summer. Since no defined storage organ or tissue has been found for vitamin D, it has been assumed that an adequate vitamin D status in winter can only be maintained by oral supplementation. Skeletal muscle cells have now been shown to incorporate the vitamin D-binding protein (DBP) from blood into the cell cytoplasm where it binds to cytoplasmic actin. This intracellular DBP provides an array of specific binding sites for 25-hydroxyvitamin D (25(OH)D), which diffuses into the cell from the extracellular fluid. When intracellular DBP undergoes proteolytic breakdown, the bound $25(\mathrm{OH}) \mathrm{D}$ is then released and diffuses back into the blood. This uptake and release of $25(\mathrm{OH}) \mathrm{D}$ by muscle accounts for the very long half-life of this metabolite in the circulation. Since $25(\mathrm{OH}) \mathrm{D}$ concentration in the blood declines in winter, its cycling in and out of muscle cells appears to be upregulated. Parathyroid hormone is the most likely factor enhancing the repeated cycling of $25(\mathrm{OH}) \mathrm{D}$ between skeletal muscle and blood. This mechanism appears to have evolved to maintain an adequate vitamin D status in winter.
\end{abstract}

Keywords: vitamin D; muscle; parathyroid hormone; vitamin D-binding protein

\section{Characterization of Vitamin D Status}

The concentration in blood serum or plasma of 25-hydroxyvitamin D [25(OH)D], which is the most plentiful vitamin D metabolite, has become established as the definitive indicator of vitamin $\mathrm{D}$ status [1,2]. When the concentration falls below a generally agreed level, (usually $50 \mathrm{nmol} / \mathrm{L}$ ), vitamin $\mathrm{D}$ status is said to be insufficient or deficient in the same way that status is defined for other small molecules derived from the environment, such as vitamins A, E, and K. However, there are three substantial differences between this measurement of vitamin $\mathrm{D}$ status and measurements of these fat-soluble micronutrients. The first is that $25(\mathrm{OH}) \mathrm{D}$ concentration in blood varies with season. Since it is derived from vitamin $\mathrm{D}$ produced in skin by the action of solar ultraviolet radiation on 7-dehydrocholesterol, the $25(\mathrm{OH}) \mathrm{D}$ levels rise during the months of summer and fall during winter, 
particularly in those people who live far from the equator [3,4]. In temperate geographical regions in winter, the intensity of solar UV light is very low in the vitamin D-producing wavelength range of 290-320 nm [5,6]. Are the lower values of $25(\mathrm{OH}) \mathrm{D}$ concentration in winter really an indication of deficiency or insufficiency of vitamin $\mathrm{D}$, if this is a universal feature of populations?

The second difference with vitamins $\mathrm{A}, \mathrm{E}$, and $\mathrm{K}$ is that there is no apparent storage organ or tissue for vitamin $\mathrm{D}$ or $25(\mathrm{OH}) \mathrm{D}$. Although vitamin $\mathrm{D}$ is found in adipose tissue, suggesting that this is a storage site $[7,8]$, it can only be released when stored fatty acids are mobilized to supply energy [9-11]. Thus, sequestered vitamin $\mathrm{D}$ in adipocytes should not be regarded as a functional store, ready to be transported to the liver and converted to $25(\mathrm{OH}) \mathrm{D}$, whenever circulating levels of this metabolite decline.

The third unique feature is that $25(\mathrm{OH}) \mathrm{D}$ has a very long residence time in blood. The half-life is very variable between 15 and 50 days [12] with a mean value in a recent study of 89 days [13]. In contrast, other hormonal steroids in blood, including the vitamin D hormone, 1,25-dihydroxyvitamin $\mathrm{D}\left(1,25(\mathrm{OH})_{2} \mathrm{D}\right)$, are cleared in minutes or hours after entering the circulation [14,15]. An explanation for this long residence time of $25(\mathrm{OH}) \mathrm{D}$ is not readily apparent, particularly because the vitamin $\mathrm{D}$ binding protein (DBP) in blood, to which $25(\mathrm{OH}) \mathrm{D}$ is tightly bound, has a comparatively short half-life of only 1-3 days and is continuously being replenished from synthesis and secretion by the liver [16-18]. Therefore, for 25(OH)D to be retained in blood for such a long time, it either has to transfer from one DBP molecule to another in the circulation or else it repeatedly passes to and from some extravascular site, binding to a new DBP molecule with each cycle. The DBP concentration in blood is in vast excess to that of $25(\mathrm{OH}) \mathrm{D}$ with only $1 \%-5 \%$ of the protein molecules having a $25(\mathrm{OH}) \mathrm{D}$ molecule bound to the single, high affinity, specific binding site [19].

This article reviews new evidence for a conservation mechanism for 25-hydroxyvitamin D by skeletal muscle cells.

\section{Evidence for Conservation of 25(OH)D}

The discovery that maternal $25(\mathrm{OH}) \mathrm{D}$ in rats was transported across the placenta and accumulated in the skeletal muscle of fetuses suggested that skeletal muscle might have a functional role in conserving this vitamin D metabolite [20]. Although the concentration of $25(\mathrm{OH}) \mathrm{D}$ in the muscle of sheep and cattle is only about $0.1-0.3 \mu \mathrm{g} / 100 \mathrm{~g}$ [21], muscle represents $30 \%-38 \%$ of body mass in humans [22] and, thus, total 25(OH)D in total skeletal muscle could be comparable to that in the circulation (Table 1).

Table 1. Comparison of total body 25(OH)D in blood plasma and skeletal muscle.

\begin{tabular}{ccc}
\hline & Blood Plasma Volume (L) & Muscle Mass (kg) \\
\hline Total for 70 kg human & $2.7-4.3 \mathrm{~L}[23]$ & $21-26.6 \mathrm{~kg}$ \#\# [22] \\
25(OH)D concentration & $20 \mu \mathrm{g} / \mathrm{L} \# \#$ & $1-3 \mu \mathrm{g} / \mathrm{kg} \# \# \#[21]$ \\
Total body 25(OH)D & $54-86 \mu \mathrm{g}$ & $21-80 \mu \mathrm{g}$ \\
\hline Assuming body mass of 70 kg, ${ }^{\# \#}$ Minimum adequate status 25(OH)D concentration, ${ }^{\# \# \# ~ A s s u m i n g ~ h u m a n ~}$ \\
muscle has similar 25(OH)D concentrations to sheep and cattle.
\end{tabular}

In addition, studies in adolescent children [24] found that plasma 25(OH)D concentration was positively correlated with total body lean mass in which the main component is skeletal muscle. Furthermore, there are now several published findings of a positive relationship between the intensity of physical exercise and the concentration of $25(\mathrm{OH}) \mathrm{D}$ in blood, e.g., [25,26], particularly in winter when there would be little exposure to solar UV light during outdoor exercise [24]. Muscle biopsies from sheep grazing outdoors in winter showed a significantly higher concentration of $25(\mathrm{OH}) \mathrm{D}$ than biopsies from sheep outdoors at the end of summer (Table 2). 
Table 2. Plasma and muscle concentrations of $25(\mathrm{OH}) \mathrm{D}$ in outdoor grazing sheep at latitude $33.9^{\circ} \mathrm{S}$. Mean values \pm Standard Error of the Mean (SEM) [27].

\begin{tabular}{ccc}
\hline Season & Plasma 25(OH) $\mathbf{D}_{3}$ & Muscle 25(OH)D \\
\hline End of summer values $(n=5)$ & $10.67 \pm 1.65 \mathrm{ng} / \mathrm{mL}$ & $0.84 \pm 0.18 \mu \mathrm{g} / 100 \mathrm{~g}$ tissue \\
End of winter values $(n=5)$ & $5.36 \pm 0.71 \mathrm{ng} / \mathrm{mL} *$ & $1.82 \pm 0.39 \mu \mathrm{g} / 100 \mathrm{~g}$ tissue * \\
\hline * Winter values are significantly different from summer values by the $t$-test $p<0.05$.
\end{tabular}

\section{Skeletal Muscle Cell Uptake of DBP}

The key discovery that pointed to a role for muscle in maintaining vitamin D status came from studying the properties of muscle cells in vitro [28]. The cell membrane was found to contain the proteins megalin and cubilin. These proteins, like those in the renal tubule cells $[29,30]$ and in hepatic stellate cells [31], transport DBP from the extracellular fluid into the cell cytoplasm. The vitamin D binding protein has two specific, high-affinity binding sites. One is for vitamin $\mathrm{D}$ and its metabolites with the highest affinity being for $25(\mathrm{OH}) \mathrm{D}(\mathrm{Kd}<1 \mathrm{nmol} / \mathrm{L})$. The other binding site is specific for filamentous actin [32,33]. A commonly held theory postulates that the actin-binding site of DBP functions to bind actin if released into blood from damaged cells and, thus, protects against intravascular coagulation [34,35]. Yet it has been known for over 30 years that DBP becomes bound to actin in skeletal muscle [36]. Some of the internalized DBP could be bound to actin in actomyosin, via its specific actin-binding site, but much of the remainder is bound to actin dispersed throughout the cytoplasm. Both megalin and DBP have also been found in human muscle biopsies [37].

The role attributed to megalin/cubilin in renal proximal tubule cells is the recovery of DBP that leaks into the glomerular filtrate. This process is credited with conserving $25(\mathrm{OH}) \mathrm{D}$ even though only $1 \%-5 \%$ of the retrieved DBP molecules would be transporting $25(\mathrm{OH}) \mathrm{D}$ [19]. The observation that genetically modified global megalin-knockout mice become vitamin D deficient has, therefore, been interpreted as evidence that renal megalin uptake of DBP prevents loss of DBP-bound 25(OH)D in urine [29]. A more plausible explanation is that muscle conservation of $25(\mathrm{OH}) \mathrm{D}$ is completely abolished in megalin-knockout mice so that the residence time of $25(\mathrm{OH}) \mathrm{D}$ in blood would be no greater than that of DBP itself. The main site of DBP clearance from blood has also been attributed to the kidney [33]. Yet, the uptake and proteolysis of DBP in the much larger mass of total body skeletal muscle would appear to be a more likely explanation for its short residence time in the circulation.

In vivo experiments with ${ }^{131}$ I-labelled DBP in rabbits revealed that DBP had a short residence time in skeletal muscle and soon underwent proteolysis [16]. DBP is a member of the albuminoid family of proteins. It is synthesized and secreted by the liver with similar characteristics to blood albumin [33]. Because albumin in the extracellular fluid in skeletal muscle is only about one-third the concentration in plasma [38], the extracellular DBP concentration will likewise be decreased to about 1.5 to $2 \mu \mathrm{mol} / \mathrm{L}$ when compared to the blood concentration of 5-6 $\mu \mathrm{mol} / \mathrm{L}$ [39]. Thus, much of the $25(\mathrm{OH}) \mathrm{D}$ in the extracellular fluid will have dissociated from the low concentration of DBP and would be able to diffuse into muscle cells where it would bind to the internalized DBP in the cell cytoplasm. In comparison with control cells such as osteoblasts, $25(\mathrm{OH}) \mathrm{D}$, is retained within myotubes (the differentiated cell type derived from myoblasts in culture, equivalent to myocytes in vivo) for a considerably longer time (Figure 1). When cytoplasmic DBP undergoes proteolysis in vivo, the bound $25(\mathrm{OH}) \mathrm{D}$ is released and would diffuse from the myocyte and return to the circulation, once again being bound to the plentiful DBP. This repeated uptake and release of 25(OH)D by the total mass of skeletal muscle cells would account for the apparent long residence time of $25(\mathrm{OH}) \mathrm{D}$ in blood plasma. 


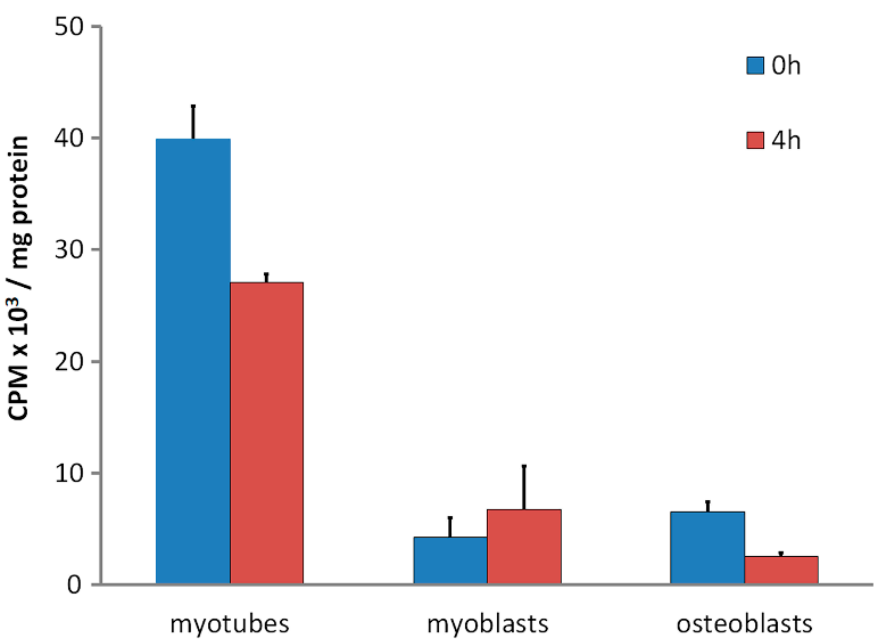

Figure 1. (Data reformatted from Reference [28]). Retention of tritiated-25(OH)D3 in C2 myotubes, C2 myoblasts and MG63 osteoblasts. Cells were incubated for $16 \mathrm{~h}$ with $\left[26,27-{ }^{3} \mathrm{H}\right] 25$-hydroxyvitamin D3 (Perkin Elmer, Waltham, MA, USA) in Dulbecco's Modified Eagle's Medium (DMEM) supplemented with serum replacement (Sigma-Aldrich, St. Louis, MO, USA) followed by 3x washes with ice cold Phosphate Buffered Saline (PBS). At this point, $0 \mathrm{~h}$ or $4 \mathrm{~h}$ later, cells were harvested, lysed, and assayed for protein by the bicinchoninic acid assay (Thermo-Scientific, Bannockburn, IL, USA) or radioactivity counted by liquid scintillation counting (see Reference [28]). Data as mean counts per minute $(\mathrm{CPM}) \pm$ Standard Error of the Mean (SEM) $(n=3$ wells/group).

An alternative explanation for the long half-life of $25(\mathrm{OH}) \mathrm{D}$ in blood could be that there is continuous entry of newly synthesized $25(\mathrm{OH}) \mathrm{D}$, perhaps from parent vitamin $\mathrm{D}$ trapped in adipose tissue. This possible steady input could be replacing a steady loss of $25(\mathrm{OH}) \mathrm{D}$ from blood, and, thus, account for an apparently long half-life. However, the long residence time in blood of tritium-labelled $25(\mathrm{OH}) \mathrm{D}$ in both mice [28] and humans [12] demonstrates that it is persistence of the same molecules in blood that is the real explanation. This phenomenon can only be explained by recycling of $25(\mathrm{OH}) \mathrm{D}$ from some extravascular region and skeletal muscle is the only candidate for that region.

Nevertheless, experiments investigating the uptake and retention of $25(\mathrm{OH}) \mathrm{D}$ in cultured muscle cells in vitro, have shown that raising the concentration of DBP in the culture medium blocks the uptake of $25(\mathrm{OH}) \mathrm{D}$ into the cells (Table 3). The higher the concentration of DBP, the lower the concentration of unbound $25(\mathrm{OH}) \mathrm{D}$. This observation fits with the interpretation that it is unbound $25(\mathrm{OH}) \mathrm{D}$ that enters muscle cells, rather than that which might be carried in, bound to DBP, via the megalin/cubilin protein internalization process. The fact that only $1 \%-5 \%$ of DBP in the circulation is transporting a specifically bound $25(\mathrm{OH}) \mathrm{D}$ molecule also indicates that transport on DBP across the cell membrane cannot be the mechanism for the intracellular accumulation of $25(\mathrm{OH}) \mathrm{D}$.

Table 3. Uptake of $\left[{ }^{3} \mathrm{H}\right]-25(\mathrm{OH}) \mathrm{D}_{3}$ by differentiated myotubes after $4 \mathrm{~h}$ in the presence of varying concentrations of D-binding protein (DBP) (Data reformatted from Reference [28]).

\begin{tabular}{ccccc}
\hline DBP Concentration & $\mathbf{0}$ & $\mathbf{1} \mathbf{~ n M}$ & $\mathbf{1 0} \mathbf{n M}$ & $\mathbf{1 0 0} \mathbf{n M}$ \\
\hline$\left[{ }^{3} \mathrm{H}\right] 25(\mathrm{OH}) \mathrm{D}$ cpm $/ \mathrm{mg}$ cell protein & $1284 \pm 147$ & $1233 \pm 67$ & $778 \pm 76 *$ & $402 \pm 20 *$ \\
\hline \multicolumn{4}{c}{$*$ Significantly different from $1 \mathrm{nmol} / \mathrm{L} \mathrm{DBP} p<0.001}$.
\end{tabular}

The accumulation of tritium-labelled $25(\mathrm{OH}) \mathrm{D}$ over $16 \mathrm{~h}$ by cultures of differentiated mouse skeletal myotube cells compared to the very low uptake by undifferentiated myoblasts and osteoblasts [40] demonstrated that some internal $25(\mathrm{OH}) \mathrm{D}$-specific binding sites were present in the myotubes but not in the other two control cell types (Figure 2). Since the culture medium during the time of these incubations did not contain DBP, the specific binding inside myotubes would have been to DBP, 
which had been internalized from the culture medium while the myotubes were differentiating from myoblasts. When myotubes were cultured with fluorescently labelled DBP for up to $24 \mathrm{~h}$ and then observed by confocal microscopy, the fluorescent protein was clearly seen within the cells (Figure 3). Some of the fluorescence was in linear streaks along the long axis of the myotubes, suggesting that some of the labelled DBP was bound to actin in the actomyosin contractile elements. However, the fluorescent pattern was also distributed generally within the cell, indicating that much of the DBP was bound to the abundant actin, known to be distributed throughout the myotube cytoplasm [41].

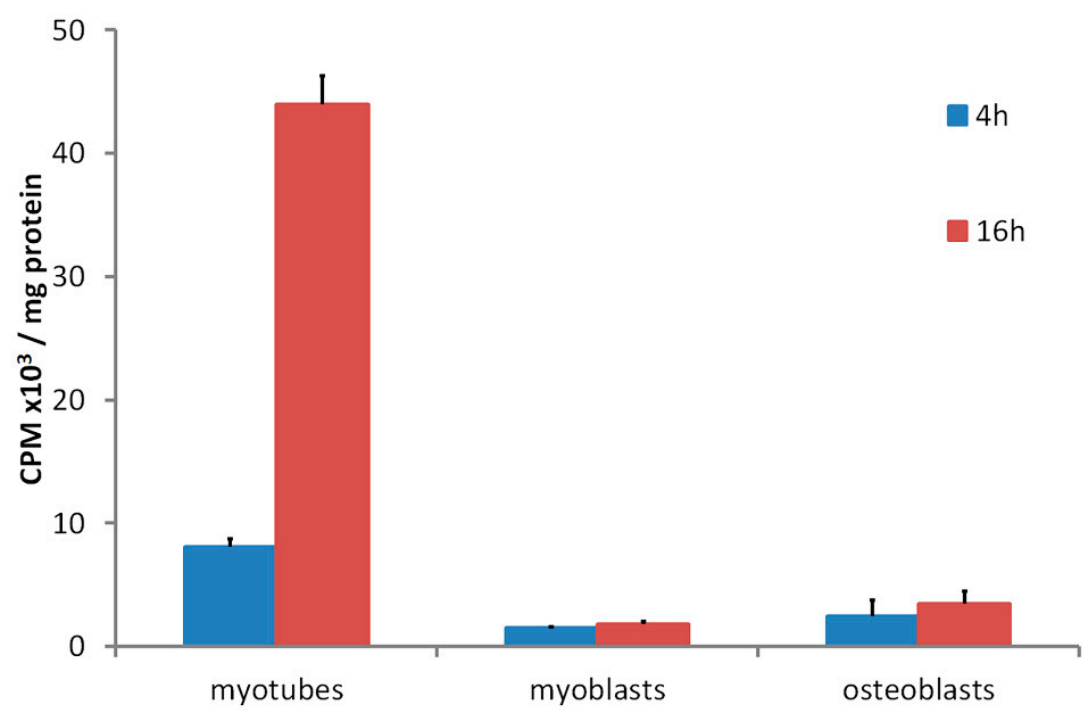

Figure 2. (Data reformatted from Reference [28]) Time dependent tritiated-25(OH)D uptake in C2 myotubes and myoblasts and MG63 osteoblasts. Cells were incubated for 4 or $16 \mathrm{~h}$ with $\left[26,27-{ }^{3} \mathrm{H}\right] 25$-hydroxyvitamin $\mathrm{D}_{3}$ in DMEM supplemented with serum replacement and followed by $3 x$ washes with ice cold PBS. At each time point, cells were harvested, lysed, and assayed for protein by the bicinchoninic acid assay or radioactivity counted by liquid scintillation counting (see Reference [28]). Data shown as means $\pm \operatorname{SEM}(n=3$ wells/group).

It now appears that the megalin/cubilin protein internalization mechanism in myocytes is not limited to DBP because other extracellular proteins, such as albumin, have been found in human skeletal muscle [37] and have also been demonstrated to be incorporated into myotube cells in culture by this mechanism (unpublished results). Thus, the endocytosis of albumin by megalin/cubilin in muscle cells is similar to this property of megalin/cubilin in renal proximal tubule cells [30]. The function of the uptake of other extracellular proteins by skeletal muscle cells in vivo is a matter of speculation. Since skeletal muscle has a high rate of protein turnover, particularly when undergoing regular physical exercise [42], the internalized proteins, including DBP, could, after proteolysis, be supplying essential amino acids for protein resynthesis. It is, therefore, conceivable that, because DBP in myotube cultures is capable of retaining 25(OH)D for many hours (Figure 1) [28], the DBP bound to cytoplasmic actin is protected from the proteolysis that other internalized proteins undergo. Nevertheless, when the cytoplasmic DBP is eventually broken down, the retained $25(\mathrm{OH}) \mathrm{D}$ would be released and could then diffuse out of the cell, bind to extracellular DBP, and return to the circulation. 

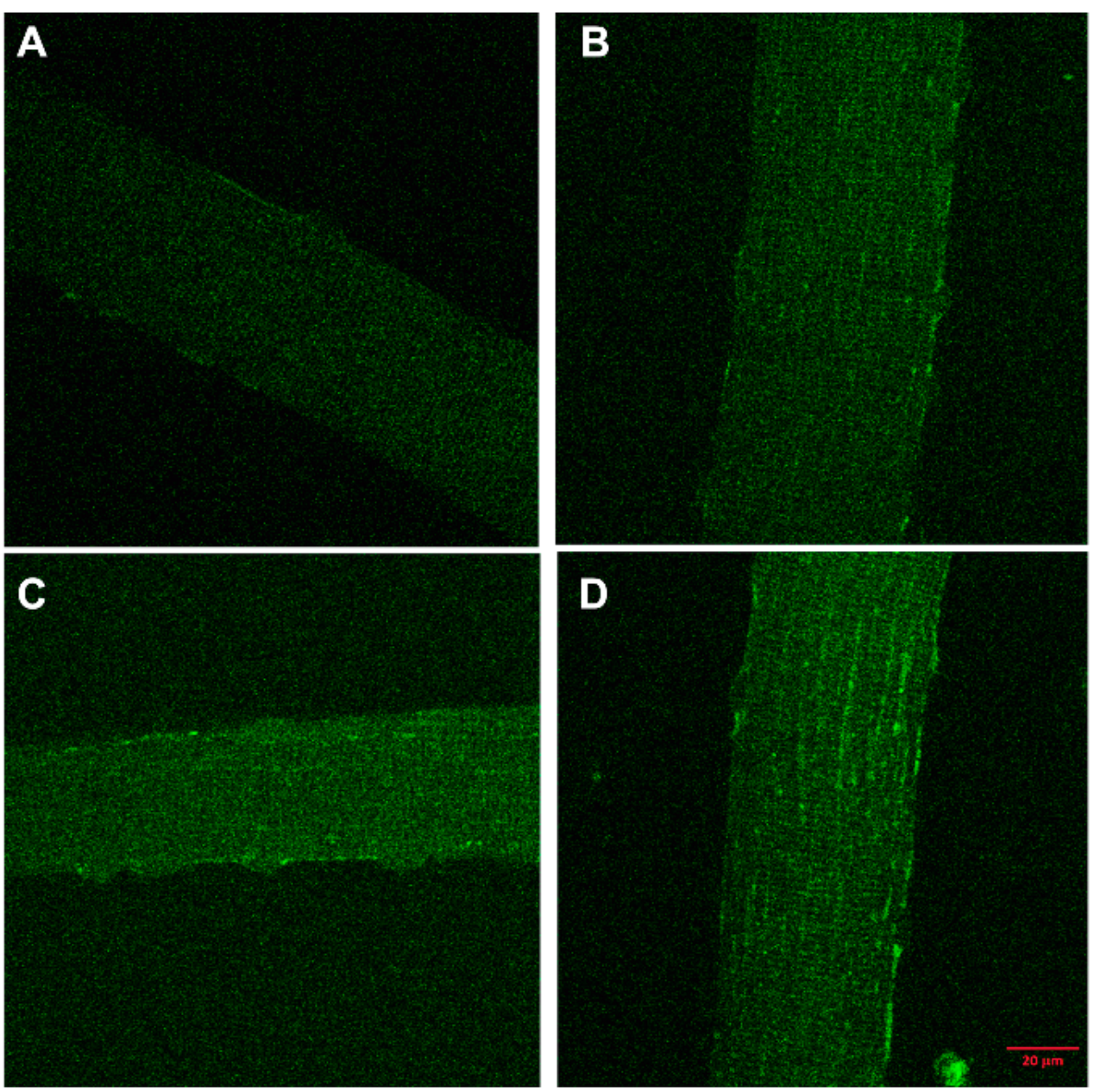

Figure 3. (Images referred to in Reference [28]). The uptake of Alexafluor488-labelled D-binding protein (DBP) into primary muscle fibers. Myofibers were isolated from the flexor digitorum brevis of euthanized Balb/c mice and incubated in quadruplicate wells on poly-L-lysine-coated glass coverslips. Fibers were incubated for $0,4,12$, or $24 \mathrm{~h}$ with $1 \mu \mathrm{mol} / \mathrm{L}$ of Alexa Fluor488-DBP (labelling kit from Molecular Probes) in DMEM supplemented with 20\% DBP-free serum replacement. Incubations were set up to finish at the same time. Cells were then fixed in paraformaldehyde for $20 \mathrm{~min}$. Fluorescent images were captured with a Zeiss LSM 510 Meta Spectral confocal microscope, using optimized saturation settings for the 24 -h time point. The fluorescence intensity can be seen increasing from (A) $0 \mathrm{~h},($ B) $4 \mathrm{~h},(\mathbf{C}) 12 \mathrm{~h}$, and (D) $24 \mathrm{~h}$.

\section{Regulation of Conservation Mechanism for 25(OH)D}

Since the effect of regular physical exercise is associated with improved maintenance of vitamin D status in winter [24], the changes in muscle protein turnover from exercise [43] may improve the efficiency of the muscle-DBP conservation mechanism for 25(OH)D. It has been reported that a diet containing small quantities of meat gives some protection against clinical vitamin D deficiency when compared to a vegetarian diet [44]. The greater supply of essential amino acids from meat proteins compared to vegetable proteins may optimize protein turnover in muscle, which could be related to the efficiency of the conservation mechanism for 25(OH)D.

It is possible that the uptake and release of $25(\mathrm{OH}) \mathrm{D}$ by myocytes in vivo is a variable process that could be modified according to its functional role. One factor that has been shown to affect the uptake and release of $25(\mathrm{OH}) \mathrm{D}$ by myotubes in culture is the vitamin $\mathrm{D}$ hormone $1,25(\mathrm{OH})_{2} \mathrm{D}[45]$. The receptor for $1,25(\mathrm{OH})_{2} \mathrm{D}$ (Vitamin D Receptor - VDR) is expressed in muscle cells, although at a low concentration [46]. Myotubes exposed to $1,25(\mathrm{OH})_{2} \mathrm{D}$ for $3 \mathrm{~h}$ show an enhanced accumulation 
of $25(\mathrm{OH}) \mathrm{D}$ over a subsequent 4 - $\mathrm{h}$ period. However, in contrast, culturing these cells for $16 \mathrm{~h}$ in the presence of $1,25(\mathrm{OH})_{2} \mathrm{D}$ produces the opposite response of a decreased accumulation of $25(\mathrm{OH}) \mathrm{D}$. Although the physiological significance of these changes is unknown, they do suggest that the uptake and release of $25(\mathrm{OH})$ D by skeletal muscle cells in vivo is potentially a VDR-regulated process.

Because the concentration of 25(OH)D in skeletal muscle of sheep (Table 2 and Reference [28]) was significantly higher in winter than in summer, during the time when plasma concentration of $25(\mathrm{OH}) \mathrm{D}$ was decreasing, it is likely that some endocrine factor was modifying the $25(\mathrm{OH}) \mathrm{D}$ retention capacity of muscle, according to changes in vitamin D status. The circulating levels of at least two hormones rise in winter and decline in summer. These are thyroid stimulating hormone (TSH) [47] and parathyroid hormone (PTH) [48]. There is no information at present to link TSH or thyroid hormone to changes in the uptake or release of $25(\mathrm{OH}) \mathrm{D}$ by skeletal muscle. However, the small increase in PTH concentration in blood plasma when $25(\mathrm{OH}) \mathrm{D}$ levels fall to $50-60 \mathrm{nmol} / \mathrm{L}$ [48], make it a candidate as a regulator of muscle uptake and release of $25(\mathrm{OH}) \mathrm{D}$.

Receptors for PTH have now been demonstrated on mouse muscle fibers and on differentiated myotubes in culture, but receptors are not found on undifferentiated myoblast cells [27]. Incubation of myotubes with low concentrations of PTH $(0.1-1 \mathrm{pmol} / \mathrm{L})$ for $3 \mathrm{~h}$, diminished the subsequent uptake of ${ }^{3} \mathrm{H}-25(\mathrm{OH}) \mathrm{D}$ over $16 \mathrm{~h}$. Conversely, the release back into the medium of ${ }^{3} \mathrm{H}-25(\mathrm{OH}) \mathrm{D}$, already accumulated by myotubes, was enhanced by the addition of low concentrations of PTH to the incubation medium [27]. Although these results demonstrate an effect of PTH on the transport of $25(\mathrm{OH}) \mathrm{D}$ into and out of myotubes, they paradoxically suggest that increased exposure of muscle cells to PTH would decrease their ability to conserve $25(\mathrm{OH}) \mathrm{D}$. The rise in PTH concentration in blood as the $25(\mathrm{OH}) \mathrm{D}$ levels fall in winter suggests that, if $\mathrm{PTH}$ is the hormone regulating muscle uptake and release of $25(\mathrm{OH}) \mathrm{D}$, then that enhanced uptake and delayed release of ${ }^{3} \mathrm{H}-25(\mathrm{OH}) \mathrm{D}$ should have been seen with cells in vitro. However, in those experiments [27], the incubation medium with added PTH did not contain any DBP. Hence, the action of PTH in those studies was compatible with the hypothesis that its effect on muscle cells would be to enhance both the breakdown of cytoplasmic DBP and its rate of uptake from extracellular fluid. The effect in vivo of enhanced DBP uptake and breakdown in muscle would be to increase the rate of cycling of $25(\mathrm{OH}) \mathrm{D}$ by muscle cells and, thus, prolong the residence time of $25(\mathrm{OH}) \mathrm{D}$ in the circulation. In the disease state of hyperparathyroidism, the greatly elevated concentration of PTH in blood results in increased loss of $25(\mathrm{OH}) \mathrm{D}$, mediated by the increased renal production of $1,25(\mathrm{OH})_{2} \mathrm{D}$, which activates the hepatic uptake and destruction of $25(\mathrm{OH}) \mathrm{D}$ [12]. In contrast, the very small increase in PTH in blood with the seasonal decline in 25(OH)D concentration does not provoke increased secretion of $1,25(\mathrm{OH})_{2} \mathrm{D}$ from the kidney. Nevertheless, that concentration of PTH observed with the seasonal fall in vitamin D status has been shown to activate the muscle PTH receptor on myocytes in vitro [27].

\section{Failure of Conservation Mechanism for 25(OH)D}

Vitamin D deficiency, as defined by a low concentration of $25(\mathrm{OH}) \mathrm{D}$ in blood, is a common condition in populations throughout the world, and especially in those in temperate geographical regions [49]. One obvious explanation for this is underexposure of people in summer to enough solar ultraviolet-B (UVB)radiation to raise their vitamin D status to the level of sufficiency [50]. Yet, even with adequate vitamin $\mathrm{D}$ status at the end of summer, many people still become deficient during the following winter [51]. If the muscle mechanism for conservation of 25(OH)D has evolved to maintain vitamin D status during the annual seasonal decline in solar ultraviolet light intensity, why do so many people become vitamin D deficient?

It is notable in the limited studies on different animal species, that DBP in the blood of fish and amphibians does not have an actin-binding site [52]. Actin affinity for DBP appears to be a feature only in reptiles, birds, and mammals, which are the species that evolved as terrestrial vertebrates, dependent on solar ultraviolet light for the maintenance of vitamin D status. Furthermore, the concentration of DBP in the blood of these terrestrial animals is considerably higher than those in fish and amphibians $[53,54]$. 
This suggests that the high concentration of apo-DBP in terrestrial animals, along with its very short residence time in blood, are characteristics compatible with its function in the cycling of $25(\mathrm{OH}) \mathrm{D}$ into and out of skeletal muscle cells.

The positive association of good vitamin D status with regular physical exercise [24-26] suggests that the metabolic activity of muscle affects its $25(\mathrm{OH}) \mathrm{D}$ conservation ability. Another indication that changes in muscle metabolism might affect its role in conserving $25(\mathrm{OH}) \mathrm{D}$ comes from studies of the consequences of malnutrition. A high incidence of clinical vitamin D-deficiency rickets in children under 6 months of age was reported in Vienna at the end of World War I [55]. This was associated with maternal malnutrition caused by food shortages in Austria. A high frequency of rickets was similarly reported in Germany after World War II [56], again, associated with malnutrition. Rickets is also frequently seen in young children in Mongolia in winter, again, related to malnutrition caused by poverty [57].

In protein/energy malnutrition there is an increased breakdown of muscle protein to meet the needs for energy and essential amino acids [58]. If this enhanced proteolysis applies to internalized DBP in myocytes, the ability of skeletal muscle to perform its role of conserving $25(\mathrm{OH}) \mathrm{D}$ would be compromised. This could explain the high prevalence of vitamin $\mathrm{D}$ deficiency in malnourished people. Likewise, if the concentration of DBP in blood is depressed in humans with protein/energy malnutrition, as has been demonstrated in rats [59], the muscle mechanism for maintaining vitamin D status could become less efficient.

\section{Conclusions}

This active cycling of 25(OH)D into and out of skeletal muscle cells explains the long residence time of $25(\mathrm{OH}) \mathrm{D}$ in blood. Perhaps then, if ways could be found to optimize this process, the prevalence of some of the diseases linked epidemiologically with low vitamin D status could be minimized. Low circulating levels of vitamins A, E, and K can be related directly to the specific pathology in their function caused by deficiency of these micronutrients. Because vitamin D has been classified as a similar micronutrient, attempts have been made to obtain evidence for a direct link between low concentrations of $25(\mathrm{OH}) \mathrm{D}$ in blood and a range of diseases such as diabetes and various cardiovascular and oncology diseases, where there are epidemiological suggestions that low vitamin D status is a causative factor in their etiology. Although the level of 25(OH)D in blood may indicate the adequacy of the vitamin $\mathrm{D}$ supply to meet requirements for production of $1,25(\mathrm{OH})_{2} \mathrm{D}$, it is not a direct indicator of the function of that hormone. Because the many regulatory functions of $1,25(\mathrm{OH})_{2} \mathrm{D}$ also involve other endocrine and gene expression variables, an epidemiological link between low vitamin $\mathrm{D}$ status and a disease process is not necessarily a cause and effect relationship. This is well illustrated by the difficulty of demonstrating health benefits of vitamin D supplementation in many clinical trials [60]. Nevertheless, if ways could be found of optimizing the efficiency of the muscle conservation mechanism for $25(\mathrm{OH}) \mathrm{D}$, perhaps, by a pharmacological agent or some exercise regime, that optimization would ensure that vitamin D status would also be optimized by a process that has evolved to adapt to seasonal changes in the vitamin D supply.

Author Contributions: Conceptualization, D.R.F., R.S.M., T.C.B.-S. and M.S.R. Methodology, M.S.R. and C.G.-T. Validation, D.R.F., R.S.M. and M.S.R. Investigation, M.S.R., M.A., D.A.P. and C.G.-T. Writing-original draft preparation, D.R.F., M.S.R. and R.S.M. Writing-review and editing, M.A. and T.C.B.-S. Visualization, M.S.R. and D.A.P. Supervision, R.S.M., D.R.F., M.S.R. and C.G.-T. Project administration, R.S.M., M.S.R. and D.R.F. Funding acquisition, R.S.M., D.R.F. and M.A. All authors have read and agreed to the published version of the manuscript.

Funding: This research was partly funded by an Australian Research Council Discovery Project Grant DP170104408 and partly by a research grant (R16100) from Zayed University.

Acknowledgments: The technical support of the Molecular Biology Facility and the Advanced Microscopy Facility of the Bosch Institute, University of Sydney and the facility officers, Donna Lai and Louise Cole, are gratefully acknowledged.

Conflicts of Interest: The authors declare no conflict of interest. 


\section{References}

1. Holick, M.F.; Binkley, N.C.; Bischoff-Ferrari, H.A.; Gordon, C.M.; Hanley, D.A.; Heaney, R.P.; Hassan Murad, M.; Weaver, C.M. Evaluation, Treatment, and Prevention of Vitamin D Deficiency: An Endocrine Society Clinical Practice Guideline. J. Clin. Endocrinol. Metab. 2011, 96, 1911-1930. [CrossRef] [PubMed]

2. Rosen, C.J.; Abrams, S.A.; Aloia, J.F.; Brannon, P.M.; Clinton, S.K.; Durazo-Arvizu, R.A.; Gallagher, J.C.; Gallo, R.L.; Jones, G.; Kovacs, C.S.; et al. IOM Committee Members Respond to Endocrine Society Vitamin D Guideline. J. Clin. Endocrinol. Metab. 2012, 97, 1146-1152. [CrossRef] [PubMed]

3. Vik, T.; Try, K.; Strømme, J.H. The vitamin D status of man at 70 degrees north. Scand. J. Clin. Lab. Investig. 1980, 40, 227-232. [CrossRef] [PubMed]

4. Parviainen, M.T.; Koskinen, T. Vitamin A, D and E status in a Finnish population-A multivitamin study. Hum. Nutr. Clin. Nutr. 1983, 37, 397-403. [PubMed]

5. Nowson, C.A.; McGrath, J.J.; Ebeling, P.R.; Haikerwal, A.; Daly, R.M.; Sanders, K.M.; Seibel, M.J.; Mason, R.S.; Working Group of Australian and New Zealand Bone and Mineral Society; Endocrine Society of Australia and Osteoporosis Australia. Vitamin D and health in adults in Australia and New Zealand: A position statement. Med. J. Aust. 2012, 196, 686-687. [CrossRef]

6. Holick, M.F. Vitamin D deficiency. N. Engl. J. Med. 2007, 357, 266-281. [CrossRef]

7. Didriksen, A.; Burild, A.; Jakobsen, J.; Fuskevåg, O.M.; Jorde, R. Vitamin D3 increases in abdominal subcutaneous fat tissue after supplementation with vitamin D3. Eur. J. Endocrinol. 2015, 172, $235-241$. [CrossRef]

8. Carrelli, A.; Bucovsky, M.; Horst, R.; Cremers, S.; Zhang, C.; Bessler, M.; Schrope, B.; Evanko, J.; Blanco, J.; Silverberg, S.J.; et al. Vitamin D Storage in Adipose Tissue of Obese and Normal Weight Women. J. Bone Miner. Res. 2017, 32, 237-242. [CrossRef]

9. Connors, M.H.; Sheikholislam, B.M.; Iria, J. Vitamin D Toxicity after Dieting in Hypoparathyroidism. Pediatrics 1976, 57, 794-796.

10. Ziaie, H.; Razmjou, S.; Jomhouri, R.; Jenabi, A. Vitamin D Toxicity; Stored and Released from Adipose Tissue? Arch. Iran Med. 2016, 19, 597-600. [PubMed]

11. Perticone, M.; Maio, R.; Sciacqua, A.; Suraci, E.; Pinto, A.; Pujia, R.; Zito, R.; Gigliotti, S.; Sesti, G.; Perticone, F. Ketogenic Diet-Induced Weight Loss is Associated with an Increase in Vitamin D Levels in Obese Adults. Molecules 2019, 24, 2499. [CrossRef] [PubMed]

12. Clements, M.R.; Davies, M.; Fraser, D.R.; Lumb, G.A.; Mawer, E.B.; Adams, P.H. Metabolic inactivation of vitamin D is enhanced in primary hyperparathyroidism. Clin. Sci. 1987, 73, 659-664. [CrossRef] [PubMed]

13. Datta, P.; Philipsen, P.A.; Olsen, P.; Bogh, M.K.; Johansen, P.; Schmedes, A.V.; Morling, N.; Wulfa, H.C. The half-life of 25(OH)D after UVB exposure depends on gender and vitamin D receptor polymorphism but mainly on the start level. Photochem. Photobiol. Sci. 2017, 16, 985-995. [CrossRef] [PubMed]

14. Mason, R.S.; Lissner, D.; Posen, S.; Norman, A.W. Blood levels of dihydroxylated vitamin D metabolites after an oral dose. Brit. Med. J. 1980, 280, 449-450. [CrossRef]

15. Schapiro, S.; Percin, C.J.; Kotichas, F.J. Half-life of plasma corticosterone during development. Endocrinology 1971, 89, 284-286. [CrossRef]

16. Haddad, J.G.; Fraser, D.R.; Lawson, D.E.M. Vitamin-D Plasma-Binding Protein-Turnover and Fate in the Rabbit. J. Clin. Investig. 1981, 67, 1550-1560. [CrossRef] [PubMed]

17. Kawakami, M.; Blum, C.B.; Ramakrishnan, R.; Dell, R.B.; Goodman, D.S. Turnover of the plasma binding protein for vitamin D and its metabolites in normal human subjects. J. Clin. Endocrinol. Metab. 1981, 53, 1110-1116. [CrossRef]

18. Abboud, M.; Rybchyn, M.S.; Rizk, R.; Fraser, D.R.; Mason, R.S. Sunlight exposure is just one of the factors which influence vitamin D status. Photochem. Photobiol. Sci. 2017, 16, 302-313. [CrossRef]

19. Haddad, J.G. Purification, characterization and quantitation of the human serum binding protein for vitamin D and its metabolites. Methods Enzymol. 1980, 67, 449-459.

20. Clements, M.R.; Fraser, D.R. Vitamin D supply to the rat fetus and neonate. J. Clin. Investig. 1988, 81, 1768-1773. [CrossRef]

21. Liu, J.; Greenfield, H.; Strobel, N.; Fraser, D.R. The influence of latitude on the concentration of vitamin D3 and 25-hydroxy-vitamin D3 in Australian red meat. Food Chem. 2013, 140, 432-435. [CrossRef] [PubMed] 
22. Janssen, I.; Heymsfield, S.B.; Wang, Z.; Ross, R. Skeletal muscle mass and distribution in 468 men and women aged 18-88 yr. J. Appl. Physiol. 2000, 89, 81-88. [CrossRef] [PubMed]

23. Sawka, M.N.; Young, A.J.; Pandolf, K.B.; Dennis, R.C.; Valeri, C.R. Erythrocyte, plasma, and blood volume of healthy young men. Med. Sci. Sports 1992, 24, 447-453. [CrossRef]

24. Foo, L.H.; Zhang, Q.; Zhu, K.; Ma, G.; Trube, A.; Greenfield, H.; Fraser, D.R. Relationship between vitamin D status, body composition and physical exercise of adolescent girls in Beijing. Osteoporos. Int. 2009, 20,417-425. [CrossRef]

25. Scragg, R.; Holdaway, I.; Jackson, R.; Lim, T. Plasma 25-hydroxyvitamin D3 and its relation to physical activity and other heart disease risk factors in the general population. Ann. Epidemiol. 1992, 2, 697-703. [CrossRef]

26. Bell, N.H.; Godsen, R.N.; Henry, D.P.; Shary, J.; Epstein, S. The effects of muscle-building exercise on vitamin D and mineral metabolism. J. Bone Miner. Res. 1988, 3, 369-373. [CrossRef]

27. Abboud, M.; Rybchyn, M.S.; Liu, J.; Gordon-Thomson, C.; Brennan-Speranza, T.C.; Cole, L.; Greenfield, H.; Fraser, D.R.; Mason, R.S. The effect of parathyroid hormone on the uptake and retention of 25-hydroxyvitamin D in skeletal muscle cells. J. Steroid Biochem. Mol. Biol. 2017, 173, 173-179. [CrossRef]

28. Abboud, M.; Puglisi, D.A.; Davies, B.N.; Rybchyn, M.; Whitehead, N.P.; Brock, K.E.; Cole, L.; Gordon-Thomson, C.; Fraser, D.R.; Mason, R.S. Evidence for a specific uptake and retention mechanism for 25-hydroxyvitamin D (25OHD) in skeletal muscle cells. Endocrinology 2013, 154, 3022-3030. [CrossRef]

29. Nykjaer, A.; Dragun, D.; Walther, D.; Vorum, H.; Jacobsen, C.; Herz, J.; Melsen, F.; Christensen, E.I.; Willnow, T.E. An endocytic pathway essential for renal uptake and activation of the steroid 25-(OH) vitamin $\mathrm{D}_{3}$. Cell 1999, 96, 507-515. [CrossRef]

30. Shiying, C.; Verroust, P.J.; Stiren, K.; Moestrup, S.K.; Christensen, E.I. Megalin/gp330 mediates uptake of albumin in renal proximal tubule. Am. J. Physiol. 1996, 271, F900-F907.

31. Gressner, O.A.; Lahme, B.; Gressner, A.M. Gc-globulin (vitamin D binding protein) is synthesized and secreted by hepatocytes and internalized by hepatic stellate cells through $\mathrm{Ca}^{(2+)}$-dependent interaction with the megalin/gp330 receptor. Clin. Chim. Acta 2008, 390, 28-37. [CrossRef]

32. Van Baelen, H.; Bouillon, R.; De Moor, P. Vitamin D binding protein (Gc-globulin) binds actin. J. Biol. Chem. 1980, 255, 2270-2272. [PubMed]

33. Bouillon, R.; Schuit, F.; Antonio, L.; Rastinejad, F. Vitamin D Binding Protein: A Historic Overview. Front. Endocrinol. 2020, 10, 910. [CrossRef] [PubMed]

34. Goldschmidt-Clermont, P.J.; Van Baelen,H.; Bouillon, R.; Shook, T.E.; Williams, M.H.; Nel, A.E.; Galbraith, R.M. Role of group-specific component (vitamin D binding protein) in clearance of actin from the circulation in the rabbit. J. Clin. Investig. 1988, 81, 1519-1527. [CrossRef] [PubMed]

35. Otterbein, L.R.; Cosio, C.; Graceffa, P.; Dominguez, R. Crystal structures of the vitamin D-binding protein and its complex with actin: Structural basis of the actin-scavenger system. Proc. Natl. Acad. Sci. USA 2002, 99, 8003-8008. [CrossRef]

36. Haddad, J.G. Human serum binding protein for vitamin D and its metabolites (DBP): Evidence that actin is the DBP binding compound in human skeletal muscle. Arch. Biochem. Biophys. 1982, 213, 538-544. [CrossRef]

37. Brennan-Speranza, T.C.; Mor, D.; Mason, R.S.; Bartlett, J.R.; Duque, G.; Levinger, I.; Levinger, P. Skeletal muscle vitamin D in patients with end stage osteoarthritis of the knee. J. Steroid Biochem. Mol. Biol. 2017, 173, 180-184. [CrossRef]

38. Reed, R.K. Albumin concentration and colloid osmotic pressure of interstitial fluid collected by wick technique from rat skeletal muscle. Evaluation of the method. Acta Physiol. Scand. 1981, 112, 1-5. [CrossRef]

39. Haddad, J.G. Plasma vitamin D-binding protein (Gc globulin): Multiple tasks. J. Steroid Biochem. Mol. Biol. 1995, 53, 579-582. [CrossRef]

40. Mason, R.S.; Rybchyn, M.S.; Abboud, M.; Brennan-Speranza, T.C.; Fraser, D.R. The role of skeletal muscle in maintaining vitamin D status in winter. Curr. Dev. Nutr. 2019, 3, nzz087. [CrossRef]

41. Schiavon, C.R.; Zhang, T.; Zhao, B.; Moore, A.S.; Wales, P.; Andrade, L.R.; Wu, M.; Sung, T.-C.; Dayn, Y.; Feng, J.W.; et al. Actin chromobody imaging reveals sub-organellar actin dynamics. Nat. Methods 2020. [CrossRef] [PubMed] 
42. Churchward-Venne, T.A.; Pinckaers, P.J.M.; Smeets, J.S.J.; Betz, M.W.; Senden, J.M.; Goessens, J.P.B.; Gijsen, A.P.; Rollo, I.; Verdijk, L.B.; van Loon, L.J.C. Dose-response effects of dietary protein on muscle protein synthesis during recovery from endurance exercise in young men: A double-blind randomized trial. Am. J. Clin. Nutr. 2020, 112, 303-317. [CrossRef] [PubMed]

43. McGlory, C.; Devries, M.C.; Phillips, S.M. Skeletal muscle and resistance exercise training; the role of protein synthesis in recovery and remodeling. J. Appl. Physiol. 2017, 122, 541-548. [CrossRef] [PubMed]

44. Dunnigan, M.G.; Henderson, J.B.; Hole, D.J.; Mawer, E.B.; Berry, J.L. Meat consumption reduces the risk of nutritional rickets and osteomalacia. Br. J. Nutr. 2005, 94, 983-991. [CrossRef] [PubMed]

45. Abboud, M.; Rybchyn, M.S.; Ning, Y.J.; Brennan-Speranza, T.C.; Girgis, C.M.; Gunton, J.E.; Fraser, D.R.; Mason, R.S. 1,25-Dihydroxycholecalciferol (calcitriol) modifies uptake and release of 25-hydroxycholecalciferol in skeletal muscle cells in culture. J. Steroid Biochem. Mol. Biol. 2018, 177, 109-115. [CrossRef]

46. Girgis, C.M.; Mokbel, N.; Cha, K.M.; Houweling, P.J.; Abboud, M.; Fraser, D.R.; Mason, R.S.; Clifton-Bligh, R.J.; Gunton, J.E. The vitamin D receptor (VDR) is expressed in skeletal muscle of male mice and modulates 25-hydroxyvitamin D (25OHD) uptake in myofibers. Endocrinology 2014, 155, 3227-3237. [CrossRef]

47. Das, G.; Taylor, P.N.; Javaid, H.; Tennant, B.P.; Green, J.; Aldridge, A.; Okosieme, O. Seasonal variation of vitamin D and serum thyrotropin levels and its relationship in a euthyroid Caucasian population. Endocr. Pract. 2018, 24, 53-59. [CrossRef]

48. Yalla, Y.; Bobba, G.; Guo, G.; Stankiewicz, A.; Ostlund, R. Parathyroid hormone reference ranges in healthy individuals classified by vitamin D status. J. Endocrinol. Investig. 2019, 42, 1353-1360. [CrossRef]

49. Hilger, J.; Friedel, A.; Herr, R.; Rausch, T.; Roos, F.; Wahl, D.A.; Pierroz, D.D.; Weber, P.; Hoffmann, K. A systematic review of vitamin D status in populations worldwide. Br. J. Nutr. 2014, 111, 23-45. [CrossRef]

50. Alfredsson, L.; Armstrong, B.K.; Butterfield, D.A.; Chowdhury, R.; de Gruijl, F.R.; Feelisch, M.; Garland, C.F.; Hart, P.H.; Hoel, D.G.; Jacobsen, R.; et al. Insufficient Sun Exposure Has Become a Real Public Health Problem. Int. J. Environ. Res. Public Health 2020, 17, 5014. [CrossRef]

51. McGee, M. Vitamin D: Insufficiency, Uncertainty and Achievability. Int. J. Vitam. Nutr. Res. 2020, 90, 1-4. [CrossRef] [PubMed]

52. Van Baelen, H.; Allewaert, K.; Bouillon, R. New Aspects of the plasma carrier protein for 25-hydroxycholecalciferol in vertebrates. Ann. N. Y. Acad. Sci. 1988, 538, 60-68. [CrossRef] [PubMed]

53. Hay, A.W.M.; Watson, G. The plasma transport proteins of 25-hydroxycholeclciferol in fish, amphibia, reptiles and birds. Comp. Biochem. Physiol. 1976, 53B, 167-172.

54. Pierens, S.L.; Fraser, D.R. The origin and metabolism of vitamin D in rainbow trout. J. Steroid Biochem. Mol. Biol. 2015, 145, 58-64. [CrossRef]

55. Chick, H. Study of rickets in Vienna 1919-1922. Med. Hist. 1976, 20, 41-51. [CrossRef]

56. McCance, R.A.; Widdowson, E.M. Studies of Undernutrition, Wuppertal 1946-49. 1. The German Background; Special Report Series; Medical Research Council: Great Britain, UK, 1951; Volume 275, pp. 1-20.

57. Fraser, D.R. Vitamin D-deficiency in Asia. J. Steroid Biochem. Mol. Biol. 2004, 89-90, 491-495. [CrossRef]

58. Whitehead, R.G.; Alleyne, G.A. Pathophysiological factors of importance in protein-energy malnutrition. Br. Med. Bull. 1972, 28, 72-79. [CrossRef]

59. Laing, C.J.; Fraser, D.R. Changes with malnutrition in the concentration of plasma vitamin $\mathrm{D}$ binding protein in growing rats. Br. J. Nutr. 2002, 88, 133-139. [CrossRef]

60. Autier, P.; Mullie, P.; Macacu, A.; Dragomir, M.; Boniol, M.; Coppens, K.; Pizot, C.; Boniol, M. Effect of vitamin D supplementation on non-skeletal disorders: A systematic review of meta-analyses and randomised trials. Lancet Diabetes Endocrinol. 2017, 5, 986-1004. [CrossRef]

Publisher's Note: MDPI stays neutral with regard to jurisdictional claims in published maps and institutional affiliations.

(C) 2020 by the authors. Licensee MDPI, Basel, Switzerland. This article is an open access article distributed under the terms and conditions of the Creative Commons Attribution (CC BY) license (http://creativecommons.org/licenses/by/4.0/). 